\title{
PERANCANGAN SISTEM INFORMASI BAGIAN ADMINISTRASI MAHASISWA DAN ALUMNI (BAMA) UNIVERSITAS MUHAMMADIYAH PONOROGO BERBASIS WEB
}

\author{
Ivan Cahyanto Prayogi ${ }^{1)}$, Adi Fajaryanto C ${ }^{2)}$, Indah Puji Astuti ${ }^{3)}$ \\ 1), 2) Program Studi Teknik Informatika, Fakultas Teknik, Universitas Muhammadiyah Ponorogo \\ 3) Program Studi S1 Teknik Informatika, Fakultas Teknik, Universitas Muhammadiyah Ponorogo \\ Jl Budi Utomo No.10, Ronowijayan, Kec. Siman, Kabupaten Ponorogo, Jawa Timur 63471 \\ Email : ivanprayogi1@gmail.com ${ }^{1)}$, adifajaryanto@umpo.ac.id ${ }^{2)}$, indahsan0912@gmail.com $^{3)}$
}

\begin{abstract}
Abstrak
Sistem Informasi Bagian Administrasi Mahasiswa dan Alumni (BAMA) merupakan suatu sistem yang membantu dalam pelayanan administrasi dengan menyajikan berbagai prosedur kebutuhan dan informasi kegiatan mahasiswa lalu disertai dengan sistem Tracerstudy untuk membantu mengetahui perkembangan alunni dan pada sistem Tracerstudy ini tersedia grafik secara otomatis guna menunjukan hasil analisis dari perkembangan alumni yang telah berkunjung. Dimana dalam merancang sistem ini digunakan alat bantu pengembangan sistem yaitu Flowchart, Context Diagram, Data Flow Diagram (DFD), dan Entity Relationship Diagram (ERD) serta dengan menggunakan bahasa pemrograman PHP dan HTML dan MySQL sebagai databasenya.
\end{abstract}

Kata kunci: Sistem Informasi, administrasi, tracerstudy.

\section{Abstract}

Student and Alumni Administration Information System (BAMA) is a system that helps in administrative services by presenting various procedures of needs and information on student activities then accompanied by a Tracerstudy system to help find out the development of the square and in this Tracerstudy system graphs are available automatically to show the results of the analysis from the development of alumni who have visited. Where in designing this system used system development tools, namely Flowcharts, Context Diagrams, Data Flow Diagrams (DFD), and Entity Relationship Diagrams (ERD) as well as by using the programming languages PHP and HTML and MYSQL as the database.

Keywords : Information Systems, administration, tracerstudy.

\section{PENDAHULUAN}

Teknologi Informasi di dalam kegiatan sehari-hari termasuk pemakaian komputer serta termasuk perangkat yang membantu pengolahan data dan media penyampaian informasi yang tepat dalam sebuah lembaga pendidikan atau akademik [1], [2].

Salah satunya penerapan teknologi informasi pada perguruan tinggi sebagai pihak pelaksana akademik untuk menunjang kegiatan kerja dengan adanya penerapan sebuah sistem informasi yang diharapkan dapat membantu mahasiswa sehingga mewujudkan lulusan berkualitas yang mampu bekerja ataupun menciptakan pekerjaan bagi masyarakat. Sebagaimana lulusan perguruan tinggi mampu bergerak dalam pembangunan sesuai pendidikannya [3].

Mahasiswa dan Alumni merupakan produk yang menunjang terhadap perkembangan universitas sehingga memiliki pengaruh peran penting dalam berlangsungnya perguruan tinggi, hal ini dirasakan karena alumni secara langsung akan bersentuhan dengan dunia kerja dan sebagai bahan evaluasi bagi perguruan tinggi [4].

Bagian Administrasi Mahasiswa dan Alumni (BAMA) Universitas Muhammadiyah Ponorogo merupakan salah satuan kerja dilingkungan Universitas Muhammadiyah Ponorogo. Satuan kerja ini merupakan pelaksana administratif yang bertanggung jawab melaksanakan pelayanan administrasi kegiatan mahasiswa dan sekaligus menjalin komunikasi dengan alumni [5]. Pada saat ini satuan kerja ini telah menggunakan berbagai cara untuk menyampaikan 
informasi antara lain melalui media sosial dan media cetak akan tetapi masih terbatas dan belum maksimal digunakan sebagai media informasi dan layanan bagi mahasiswa dan alumni, akibat dari masalah tersebut terhambatnya kelancaran informasi mahasiswa dan alumni.

BAMA perlu mengupayakan cara efektif dan efisien guna menunjang untuk menyesuaikan dunia pendidikan dengan industri, maka BAMA membutuhkan untuk mempermudah pelayanan kepada mahasiswa dan alumni.

Berdasarkan permasalahan diatas, maka sangat perlu untuk dibuatnya sebuah sistem informasi berbasis web yang membantu proses informasi mahasiswa dan alumni.

\section{DASAR TEORI}

a. Mahasiswa dan Alumni

Mahasiswa dan Alumni adalah salah satu faktor yang menunjang terhadap perkembangan universitas, tempat semua kegiatan dan administrasi berlangsung, sehingga mahasiswa memiliki pengaruh peran penting dalam berlangsungnya universitas, oleh karena itu mahasiswa mengandalkan adanya perbuatan, adanya penerapan rangkaian sistem, dan dapat mempermudah operasional atau akses kegiatan dan administrasi dalam sebuah lembaga akademik [6].

b. Sistem Informasi

Sistem Informasi dapat didefinisikan sebagai berikut:

b. Suatu sistem yang dibuat oleh manusia yang terdiri dari komponen-komponen dalam organisasi untuk mencapai suatu tujuan yaitu menyajikan informasi

c. Sekumpulan Prosedur Organisasi yang pada saat dilaksanakan akan memberikan informasi bagi pengambilan keputusan dan/ atau untuk mengendalikan organisasi.

d. Suatu sistem didalam suatu organisasi yang mempertemukan kebutuhan pengolahan transaksi, mendukung operasi, bersifat manajerial, dan kegiatan strategi, dari suatu organisasi dan menyediakan pihak luar tertentu dengan laporan-laporan [7].

c. Tracer Study

Tracer Study atau disebut Tracer alumni adalah Rekam jejak alumni setelah selesai melakukan proses pendidikan di perguruan tinggi atau universitas. Secara umum mengeksplorasi perspektif unik dari lulusan pendidikan tinggi mengenai kontribusi dunia pendidikan terhadap kehidupan mereka setelah lulus.

Sebuah tracer study adalah survey lulusan atau alumni yang mencoba untuk jejak kegiatan lulusan dari institusi pendidikan, menjelaskan bahwa tracer study memungkinkan menghubungkan lulusan dari suatu universitas tertentu melalui sistem yang dinamis dan dapat diandalkan untuk menentukan jalan hidup atau gerakan mereka. Hal ini tentu untuk memungkinkan evaluasi dari hasil pendidikan dan pelatihan yang diperoleh dari universitas serta evaluasi karir dan prospek kerja lulusan di masa depan [8].

Menurut Romi Mardela, tracer studi adalah cara untuk melacak alumni, mengetahui kondisi alumni, bagaimana mereka bekerja, kompetensi yang dimiliki. Tracer study juga merupakan evaluasi hasil pendidikan, karena mengkaji transisi antara pendidikan di universitas dengan dunia profesional. Seberapa jauh yang mereka dapatkan dan kontribusi pendidikan terharap karir [9].

\section{METODOLOGI PENELITIAN}

Metode penelitian yang digunakan adalah studi pustaka dan pengumpulan kebutuhan, yaitu melakukan kajian pustaka mencari referensi dari sumber yang berkaitan dengan permasalahan sehingga dapat suatu bahan dasar untuk pengembangan dalam memecahkan masalah. Sedangkan metode pengembangan sistem yang digunakan adalah dengan menggunakan metode waterfall.

a. Analisis Kebutuhan

Merupakan tahapan analisa kebutuhan sistem yang akan dibangun dengan melakukan studi kasus pada BAMA Universitas Muhammadiyah Ponorogo tujuannya agar memahami dan mengerti permasalahan untuk dipakai sebagai sumber data.

b. Perancangan (Desain) 
Pada tahapan ini bagi pengembang untuk merancang gambaran proses sistem dari hasil analisis kemudian diterapkan kedalam bentuk arsitektur perangkat lunak yang mudah di pamahi seperti Flowchart dan sebagainya.

c. Pemrograman (Coding)

Tahapan implementasi sistem pembuatan program Sistem Informasi Bagian Administrasi Mahasiswa dan Alumni.

d. Pengujian (Testing)

Setelah Pemrograman selesai diimplementasikan maka pengujian dapat dilakukan guna penyesuaian hasil yang dikeluarkan [10].

Pada penelitian ini sistem yang akan dibangun memiliki beberapa fitur, diantaranya Fitur pertama yaitu untuk sistem informasi kemahasiswaan dan Fitur kedua yaitu sistem tracerstudy untuk alumni pada website. Untuk menentukan ruang lingkup sistem yang dibangun diperlukan perencanaan logika sistem yang selanjutnya dijabarkan dalam bentuk, Flowchart, Diagram Context, Data Flow Diagram (DFD) Entity Relationship Diagram (ERD). Desain Flowchart sistem informasi bagian administrasi mahasiswa dan alumni universitas muhammadiyah ponorogo berbasis web dapat dilihat pada Gambar 1.
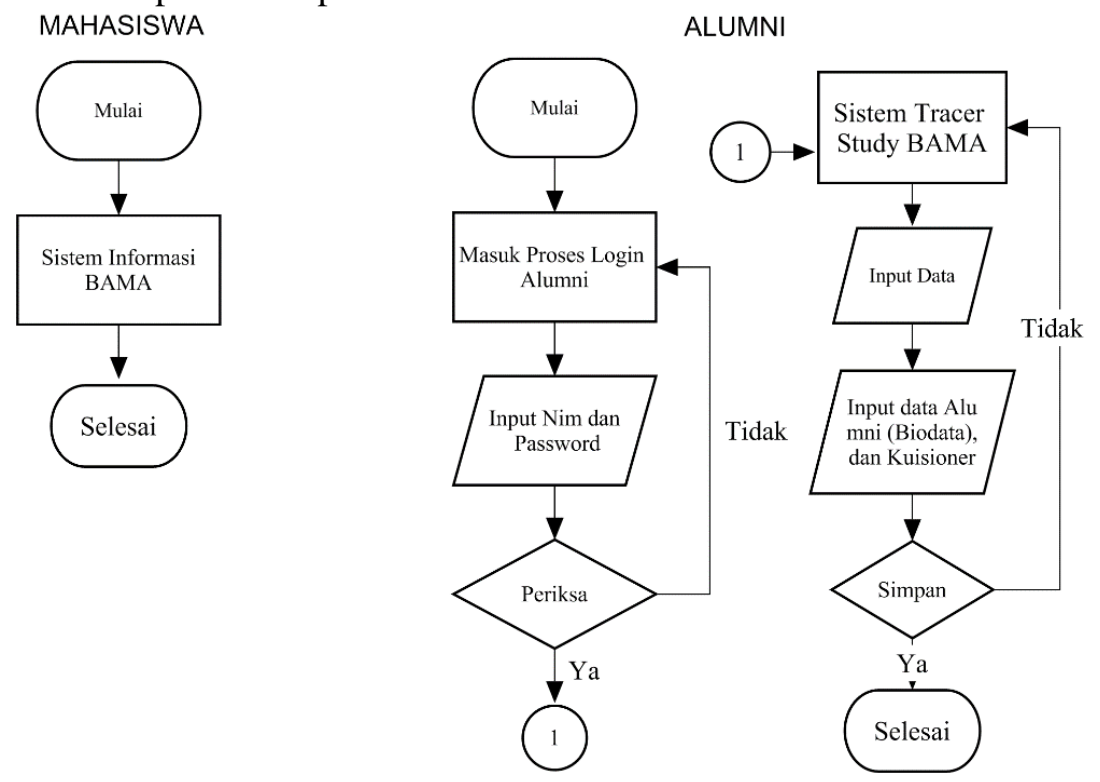

Gambar 1. Flowchart User

Pada Gambar 1 dijelaskan bahwa user dibagi menjadi dua yaitu Mahasiswa dan Alumni diantaranya memiliki hak akses yang berbeda, Mahasiswa hanya dapat mengakses langsung ke halaman utama sistem dan sub sistem, jika Alumni dapat mengakses keseluruhan termasuk sub sistem tracerstudy khusus alumni dan mempunya akses login dari masing-masing nim yang dimiliki alumni tersebut. Desain Diagram Context sistem informasi bagian administrasi mahasiswa dan alumni Universitas Muhammadiyah Ponorogo berbasis web dapat dilihat pada Gambar 2.

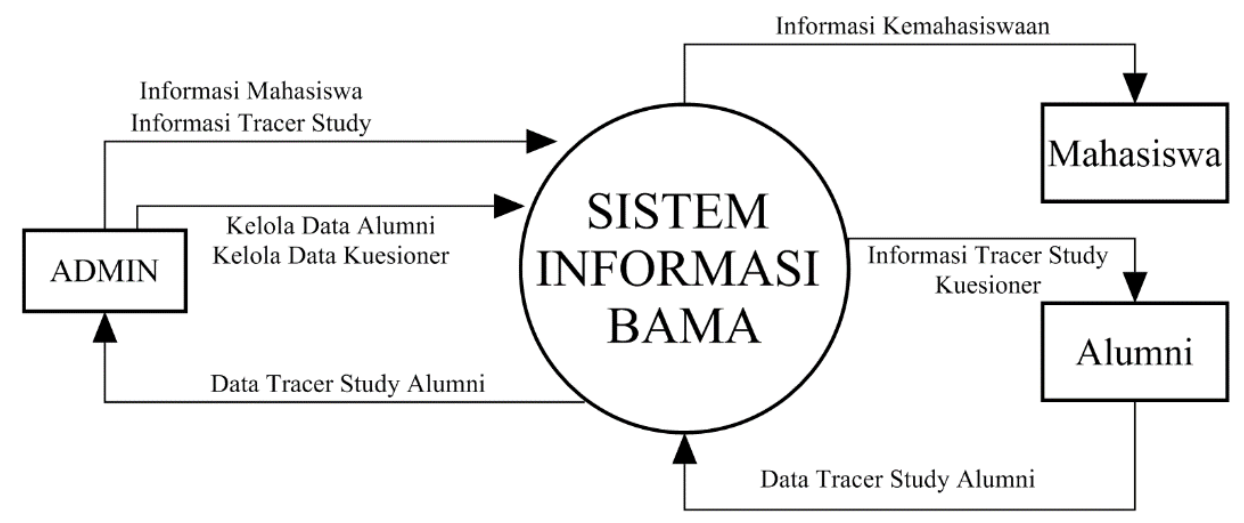

Gambar 2. Diagram Context 
Pada Gambar 2 Diagram Context terdapat 3 Proses diantaranya, Proses Informasi Kemahasiswaan dan Tracer Study admin dapat melakukan input informasi pada sistem, Proses Input Data dan Lokasi Pekerjaan, admin dan alumni dapat melakukan input data dan lokasi pekerjaan alumni, Proses Kuesioner, admin dapat input beberapa data kuesioner yang di sistem dan alumni dapat mengisi data kuesioner yang tersedia di sistem. . Desain Data Flow Diagram (DFD) sistem informasi bagian administrasi mahasiswa dan alumni Universitas Muhammadiyah Ponorogo berbasis web dapat dilihat pada Gambar 2.

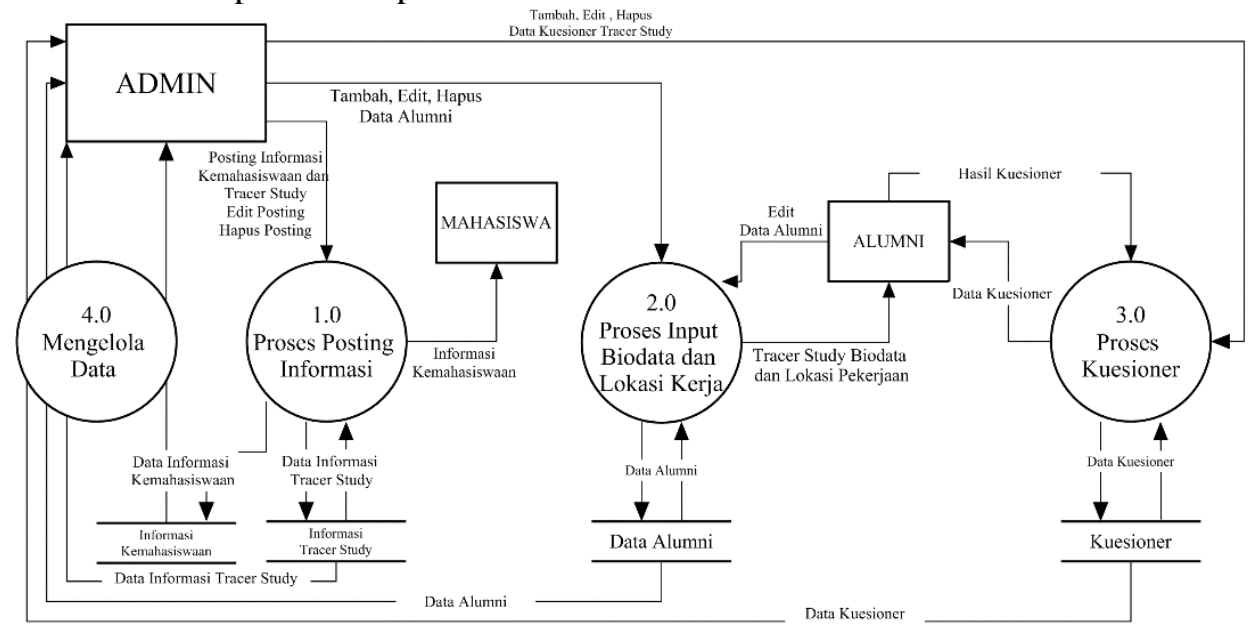

Gambar 3. Data Flow Diagram (DFD)

Pada Gambar 3 Data Flow Diagram terdapat 3 Proses diantaranya, Proses Informasi Kemahasiswaan dan Tracer Study admin dapat melakukan input informasi pada sistem, Proses Input Data dan Lokasi Pekerjaan, admin dan alumni dapat melakukan input data dan lokasi pekerjaan alumni, Proses Kuesioner, admin dapat input beberapa data kuesioner yang di sistem dan alumni dapat mengisi data kuesioner yang tersedia di sistem. . Desain Data Flow Diagram (DFD) sistem informasi bagian administrasi mahasiswa dan alumni Universitas Muhammadiyah Ponorogo Berbasis web dapat dilihat pada Gambar 4.

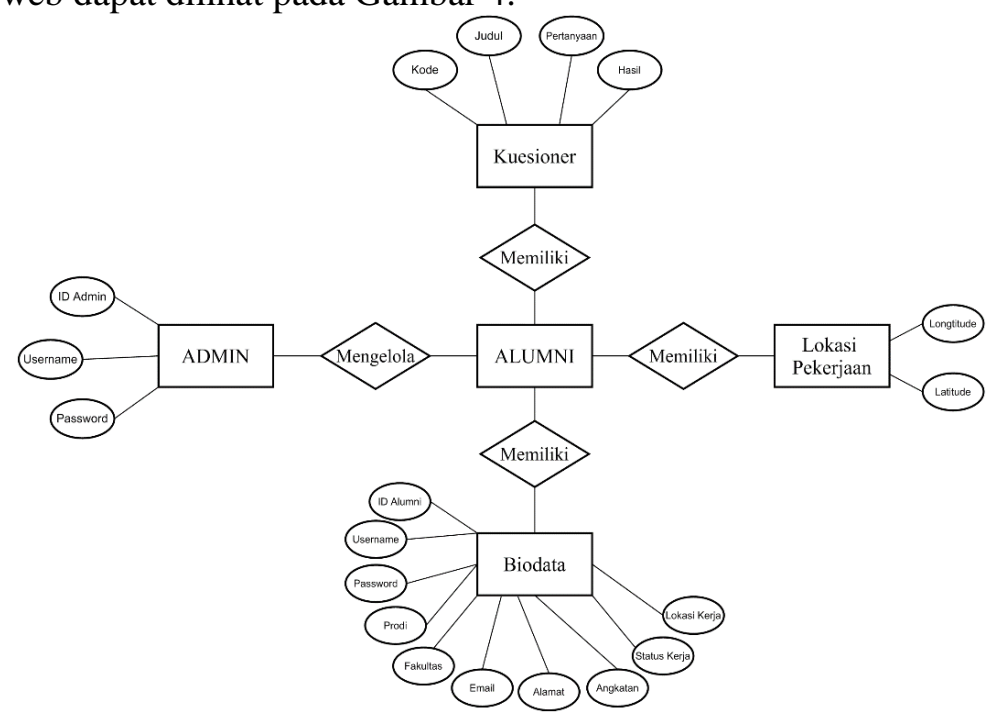

Gambar 4. Entity Relationship Diagram (ERD)

Admin memiliki 3 atribut dapat mengelola Alumni yang terdiri dari 3 Entitas yaitu Biodata memiliki 10 artibut diantaranya id, username, password, prodi, fakultas, email, alamat, angkatan, status kerja, dan lokasi kerja. Kuesioner memiliki 4 atribut diantaranya kode, judul, pertanyaan, dan hasil. dan Lokasi pekerjaan memiliki 2 atribut diantaranya longtitude dan latitude. 


\section{HASIL DAN PEMBAHASAN}

Penelitian ini menghasilkan sebuah aplikasi Sistem Informasi Bagian Administrasi Mahasiswa dan Alumni Universitas Muhammadiyah Ponorogo. salah satu yang terpenting dalam sebuah sistem adalah desain antarmuka, tampilan dalam sistem ini terdiri dari halaman home sistem kemahasiswaan, halaman desain halaman tracerstudy, dan desain halaman admin.

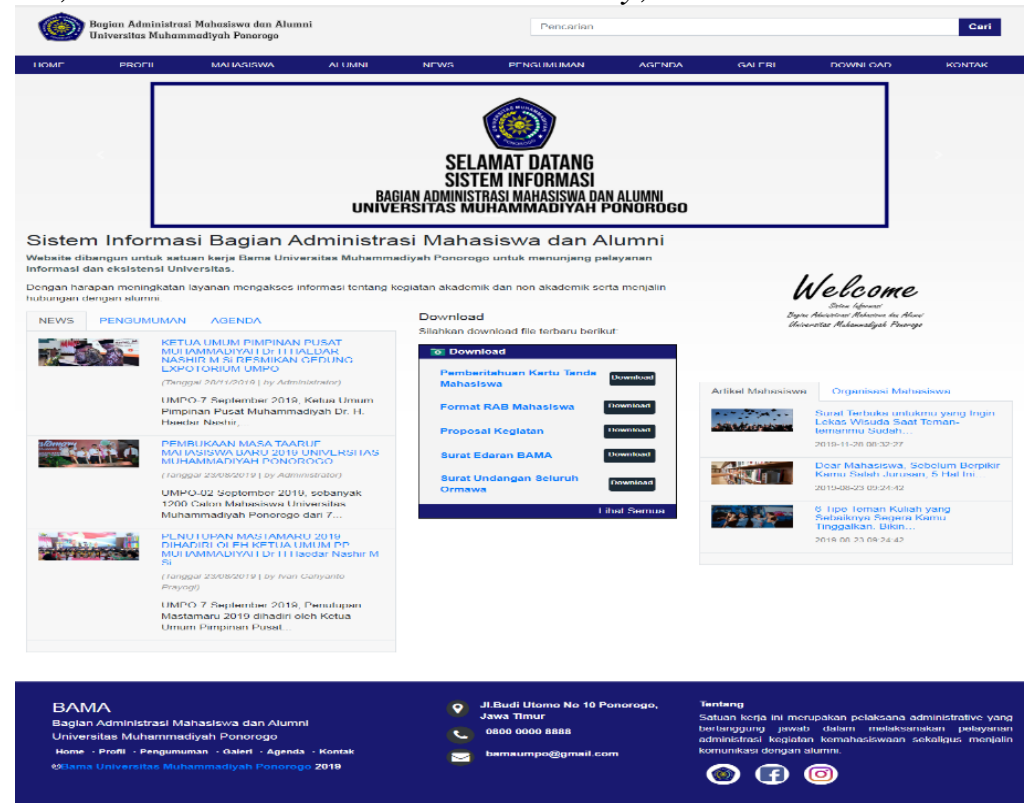

Gambar 5. Tampilan Sistem Kemahasiswaan

Berikut tampilan halama sistem kemahasiswaan pada gambar 5, terdapat profil , menu mahasiswa, alumni, informasi berita dan pengumuman secara umum tentang kemahasiswaan, agenda kegiatan, galeri dan kontak admin.

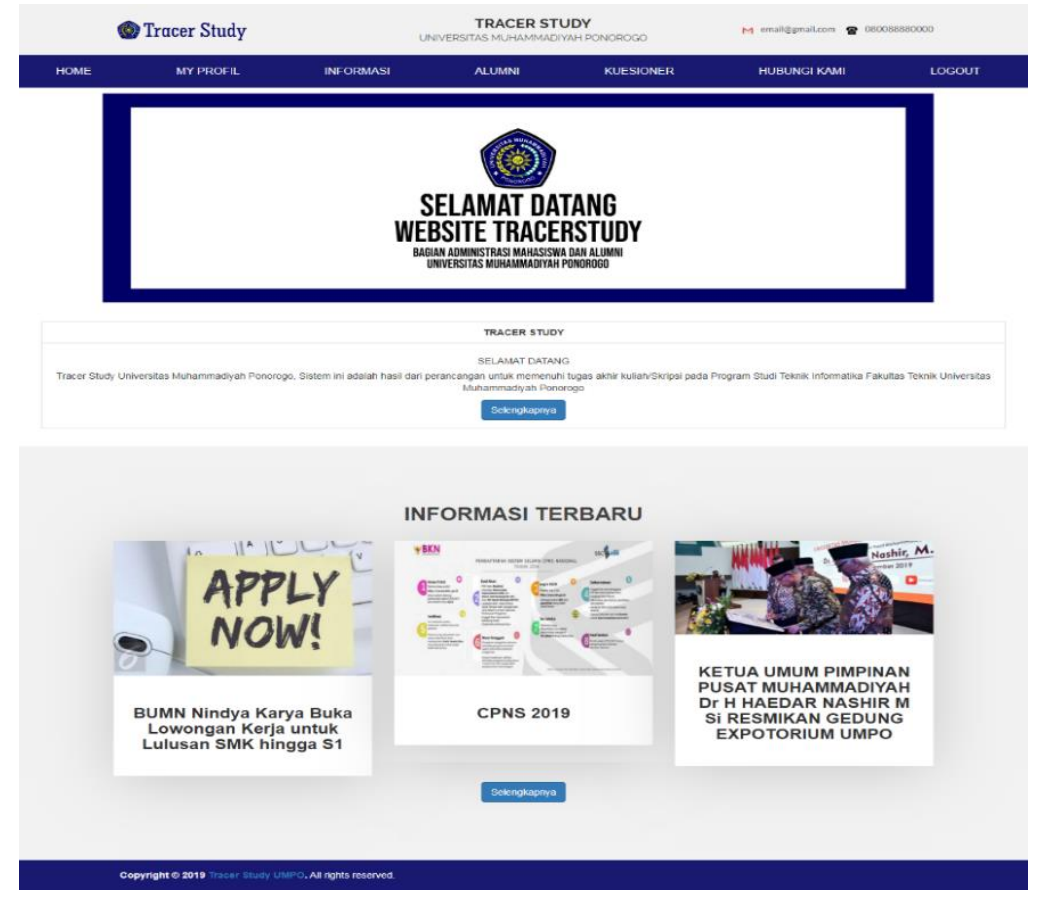

Gambar 6. Tampilan Sistem Tracer Study

Pada Gambar 6 tampilan sistem Tracer Study, terdapat menu biodata, informasi umum mengenai alumni ataupun lowongan pekerjaan, menu alumni untuk lacak alumni lain dan pekerjaannya, form kuesioner, dan hubungi admin. 


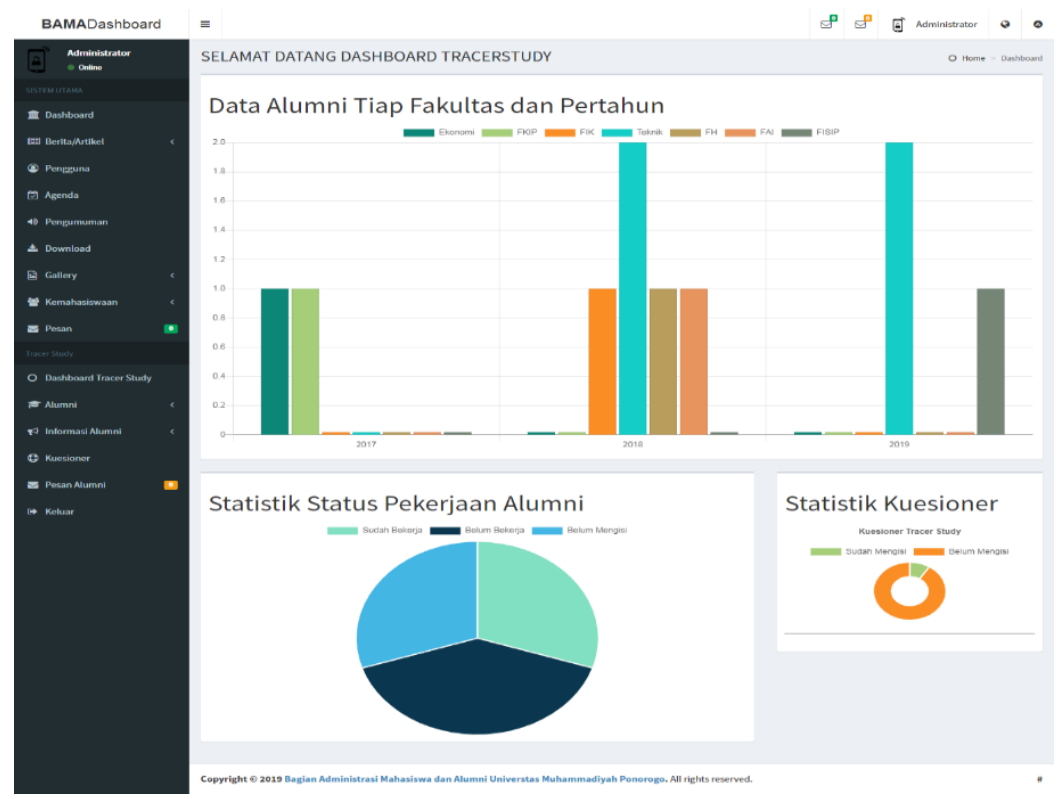

Gambar 7. Tampilan Sistem Administrator

Dari hasil sistem yang telah dirancang tampilan sistem informasi bagian administrasi mahasiswa dan alumni Universitas Muhammadiyah Ponorogo berbasis web dengan menggunakan bahasa pemograman PHP dan sistem basis data MySQL, maka sistem ini dapat diterapkan kepada pengguna yaitu mahasiswa dan alumni Universitas Muhammadiyah Ponorogo.

\section{KESIMPULAN}

Berdasarkan dari pembahasan dan hasil penelitian ini, maka penulis membuat kesimpulan sebagai berikut:

1. Sistem ini dirancang menggunakan model pengembangan Waterfall serta Aplikasi PHP dan Mysql untuk mengimplementasikan pelayanan administrasi dan informasi kepada mahasiswa dan alumni.

2. Sistem ini dapat dipergunakan untuk media informasi dan mengelola data tracerstudy alumni berbasis web.

Saran

Untuk memastikan bahwa sistem ini dapat digunakan secara mudah bagi pengguna maka diperlukannya Usability Testing untuk evaluasi sistem yang telah dirancang.

\section{Daftar Pustaka}

[1] F. Cobantoro, "ANALISA QoS (QUALITY OF SERVICE) PADA JARINGAN RT-RW NET DENGAN KENDALI RASPBERRY PI,” Netw. Eng. Res. Oper., vol. 4, no. 1, pp. 31-36, 2018.

[2] A. Nuari, "Sistem Informasi Tracer Study Pada Universitas Islam Negeri Raden Fatah Palembang Berbasis Web Sistem Informasi Tracer Study Pada Universitas Islam Negeri Raden Fatah Palembang," Universitas Islam Negeri Raden Fatah Palembang, 2015.

[3] N. Fajaryati, S. Pambudi, P. Priyanto, T. Sukardiyono, A. D. W. Utami, and B. Destiana, "Studi Penelusuran (Tracer Study) Terhadap Alumni Program Studi Pendidikan Teknik Informatika Jurusan Pendidikan Teknik Elektronika Fakultas Teknik Universitas Negeri Yogyakarta," Elinvo (Electronics, Informatics, Vocat. Educ., vol. 1, no. 1, pp. 44-45, 2015.

[4] M. Saleh and N. Safriadi, "Tracer Study Alumni Fakultas Teknik Universitas Tanjungpura Dengan Sistem Informasi Berbasis Web," J. ELKHA, vol. 4, no. 1, pp. 3844, 2012.

[5] Bama, "Bagian Administrasi Mahasiswa dan Alumni," 2019. .

[6] S. Anwar, "Perilaku Mahasiswa Jurusan Ilmu Perpustakaan Dalam Menyelesaikan 
Tugas-Tugas Mata Kuliah,” 2017.

[7] I. P. M. Gunawan, A. Sukmaaji, and E. Sutomo, "Pengembangan Sistem Informasi Pendataan Jemaat Gereja Masehi Advent Hari Ketujuh Konferens Jawa Kawasan Timur Berbasis Web," Sist. Inf., vol. 3, no. 2, pp. 72-77, 2014.

[8] G. Karyono and N. Hermanto, "Rancang Bangun Sistem Tracer Study Online pada STMIK AMIKOM Purwokerto," in Serminar Nasional Teknologi Informasi \& Komunikasi Terapan (Semantik 2013), 2013, vol. 3, no. November, pp. 126-133.

[9] M. Khair, I. Fitri Astuti, and D. M. Khairina, "Alumni Tracer System Berbasis Web (Studi Kasus Fakultas Matematika Dan Ilmu Pengetahuan Alam)," in Prosiding Seminar Sains dan Teknologi FMIPA Unmul Periode Maret 2016, Samarinda, Indonesia, 2016.

[10] Y. Firmansyah, "Penerapan Metode SDLC Waterfall Dalam Pembuatan Sistem Informasi Akademik Berbasis Web Studi Kasus Pondok Pesantren Al-Habi Sholeh Kabupaten Kubu Raya, Kalimantan Barat,” vol. 4, no. 1, 2018. 